\title{
Program badawczy SETI a teoria inteligentnego projektu
}

\section{Wprowadzenie}

Program badawczy SETI (poszukiwanie inteligencji pozaziemskiej) jest czasem wykorzystywany jako przykład tego, że wykrywanie „projektu” — używając nazewnictwa zwolenników teorii inteligentnego projektu (ID — od Intelligent Design) - może być postrzegane jako działalność naukowa. Twierdzi się w związku z tym, że skoro zarówno SETI, jak i ID zajmują się wykrywaniem działań inteligentnego projektanta, to oba te programy należy traktować na równi. Często podkreśla się też, że program SETI uważany jest przez większość uczonych za dobrze ugruntowany projekt o naukowym charakterze, natomiast ID jest odrzucana jako zakamuflowana kreacjonistyczna próba wprowadzenia nadnaturalizmu do nauki. Takie rozumowanie jest wadliwe, gdyż jego podstawą jest uproszczona interpretacja tego, czym SETI się zajmuje: w rzeczywistości w ramach tego programu nie stara się wykazać istnienia innej cywilizacji. Wręcz przeciwnie — zakłada się tam, że taka cywilizacja istnieje i próbuje skontaktować się z nami w jak najbardziej optymalny sposób, a badacze SETI próbują tę wysłaną do nas wiadomość odszukać. Jest to powiązane z szerszym problemem, mianowicie, że rozumowanie wykorzystywane w ramach SETI jest często źle przedstawiane $\mathrm{i}$ - w konsekwencji - źle rozumiane. W uproszczonej i błędnej postaci rozumowanie to często opisuje się w następujący sposób:

Dr ADAm Trybus — Uniwersytet Zielonogórski, e-mail: a.trybus@ifil.uz.zgora.pl.

(c) Copyright by Adam Trybus \& Filozoficzne Aspekty Genezy. 
Jeśli wykryty zostanie sygnał wąskopasmowy o takiej a takiej charakterystyce, oznacza to, że pochodzi on od innej cywilizacji.

W takiej postaci porównuje się powyższe zdanie do następującego twierdzenia wykorzystywanego w ramach ID:

Jeśli zaobserwujemy zjawisko charakteryzujące się wyspecyfikowaną/nieredukowalną złożonością, oznacza to, że zostało ono zaprojektowane.

W rzeczywistości jednak rozumowanie w ramach SETI powinno być raczej przedstawione w następujący sposób.

Inna cywilizacja wysłała sygnał, który my od razu rozpoznalibyśmy jako niepochodzący z natury. A zatem, jeśli wykryty zostanie sygnat waskopasmowy o takiej a takiej charakterystyce, oznacza to, że pochodzi on od innej cywilizacji.

Najwyraźniej w argumentacji na rzecz tego, że SETI jest programem podobnym do ID, uwaga skupiona jest tylko na tym ostatnim fragmencie rozumowania, a pomijany jest najważniejszy jego element. Głównym celem tego artykułu jest szczegółowy opis tego rozumowania i porównanie go z tym, wykorzystywanym $\mathrm{w}$ ramach ID. W ten sposób uwidocznione zostaną różnice między tymi dwoma podejściami. Twierdzę, że żaden intelektualnie uczciwy opis ID nie powinien powielać uproszczonej wersji rozumowania wykorzystywanego w ramach SETI.

Nie chciałbym wchodzić w dyskusję na temat naukowości ID. Na potrzeby tego artykułu zakładam, że potencjalny program badawczy ID wykorzystywałby wyłącznie narzędzia i techniki naukowe i przynajmniej w tym sensie był zgodny z przyjętą praktyką naukową.

Temat relacji między SETI a ID był już oczywiście w literaturze podejmowany. Zwolenników koncepcji, że oba te przedsięwzięcia powinny być traktowane jako $\mathrm{w}$ istotnym sensie powiązane ze sobą, krytykuje się z metodologicznego punktu widzenia. ${ }^{1}$ Twierdzi się również, że w ramach SETI mamy do czy-

\footnotetext{
${ }^{1}$ Por. Robert $\mathrm{CAMP}_{\mathrm{A}}$, „Czy teoria inteligentnego projektu może być naukowa w tym samym
} 
nienia $\mathrm{z}$ analizą prostego sygnału, którego cechą charakterystyczną jest sztuczność, i że w związku z tym narzędzia badawcze powiązane z badaniem nieredukowalnej złożoności, proponowane na gruncie ID, nie mają tu zastosowania. ${ }^{2}$

\section{Czym jest SETI}

Pierwsza kwestia dotyczy tego, czym naprawę jest SETI. Jak powszechnie wiadomo, nazwa stanowi skrót od „Search for Extraterrestrial Intelligence” i jako taka może opisywać dowolną aktywność tego typu. W tym artykule skupiam się na konkretnym przykładzie takiej działalności, mianowicie na badaniach prowadzonych w ramach SETI Institute. ${ }^{3}$ Jednakże nawet w samym instytucie prowadzi się badania różnego typu, których większość nie mieści się w zakresie tego artykułu. Zdecydowanie najbardziej zaawansowanym i metodycznym przedsięwzięciem jest analiza fal radiowych o częstotliwości $1420 \mathrm{MHz}$. Frank Drake zainicjował tego typu badania w latach sześćdziesiątych dwudziestego wieku, motywowany próbami oszacowania prawdopodobieństwa istnienia obcych cywilizacji. Niezależnie od niego, i nieco wcześniej, Giuseppe Cocconi (włoski fizyk znany ze swojej pracy w CERN) oraz Philip Morrison (fizyk, który brał udział w Projekcie Manhattan) napisali artykuł zatytułowany „Searching for Interstellar Communications", który opublikowano w Nature. W tym artykule podali oni założenia programu badawczego o dokładnie takim samym charakterze, co propozycja Drake'a. ${ }^{4}$ Ów tekst często uważany jest też za podstawę późniejszych badań w ramach SETI. ${ }^{5}$ Wszystkie poniższe analizy oparte są tyl-

sensie, co program SETI?", przeł. Piotr Wołkowski, Filozoficzne Aspekty Genezy 2009/2010, t. 6/7, s. 161-173, http://www.nauka-a-religia.uz.zgora.pl/images/FAG/2009-2010.t.6-7/art.08.pdf (04.11.2015).

${ }^{2}$ Por. Seth Shostak, „SETI a teoria inteligentnego projektu”, przeł. Dariusz Sagan, Filozoficzne Aspekty Genezy 2009/2010, t. 6/7, s. 155-160, http://www.nauka-a-religia.uz.zgora.pl/ima ges/FAG/2009-2010.t.6-7/art.07.pdf (04.11.2015).

${ }^{3}$ SETI Institute $\mathrm{w}$ istocie jest organizacją non-profit, a badacze związani z nią pochodzą z różnych ośrodków (najczęściej są powiązani z NASA).

${ }^{4}$ Por. Giuseppe Cocconi and Philip Morrison, „Searching for Interstellar Communications”, Nature 1959, vol. 184, no. 4690, s. 844-846.

${ }^{5}$ Por. np. „History of SETI”, http://archive.seti.org/seti/seti-background/ (04.11.2015). 
ko na tym artykule i związane są z tak rozumianym programem SETI, jednakże wnioski płynące $\mathrm{z}$ tych analiz mogą mieć szersze zastosowanie.

\section{SETI jako teoria naukowa}

Na wstępie należy zauważyć, że SETI nie jest typowym przykładem programów, jakie rozwija się w nauce. Sami badacze zaangażowani w SETI przyznają, że dla wielu ludzi to, czym się zajmują, należy bardziej do domeny science fiction. Można powiedzieć, że finansowanie prac badawczych w ramach SETI napotykało problemy właśnie ze względu na ich specyficzny status. Poniżej przedstawiam jedną z możliwości rekonstrukcji listy założeń opisanych w wymienionym artykule. Poniższa wersja jest nieco uogólniona i pominięte zostały szczegóły nieistotne z punktu widzenia niniejszego artykułu. W nawiasach kwadratowych znajdują się komentarze dotyczące konkretnych założeń, najczęściej opisujące ich uzasadnienie.

[1] Istnieją planety, na których rozwija się życie [biorąc za przykład nasz własny układ słoneczny i fakt, że liczba gwiazd, a zatem planet, jest ogromna].

[2] Istnieją planety, na których życie rozwinęło się na tyle, że powstała cywilizacja, która potrafi nawiązać kontakt na kosmiczne odległości [analogia do ludzi].

[3] Są planety, na których rozwinęły się wspomniane wyżej cywilizacje istniejące bardzo długo, nawet w skali kosmicznej [ekstrapolacja doświadczenia ludzkiego].

[4] Niektóre z tych cywilizacji rozpoznały nasze słońce jako źródło życia i chcą nawiązać kontakt [myślenie życzeniowe, wciąż poprzez analogię do ludzi].

[5] Cywilizacje takie używają do komunikacji kanału, który ułatwiłby nam odkrycie wysłanego sygnału i zaklasyfikowanie go jako niepochodzącego z natury [ludzie by właśnie tak uczynili].

[6] Taki kanał posiadałby takie a takie cechy [biorąc pod uwagę obecny stan wiedzy]. 
Krótko mówiąc, istnieje pewne prawdopodobieństwo, że obcy chcą nawiązać z nami kontakt i wysłali sygnał w taki sposób, by było dla nas oczywiste, iż nie stanowi on zjawiska naturalnego. Biorąc pod uwagę obecny stan wiedzy, takim sygnałem mógłby być ten nadany w wąskim zakresie częstotliwości o takiej a takiej charakterystyce. A zatem, jeśli wykryty zostanie sygnat waskopasmowy o takiej a takiej charakterystyce, oznacza to, że pochodzi on od innej cywilizacji. Warto zauważyć, jak słabe wydają się powyższe założenia, biorąc pod uwagę ich uzasadnienia. Rzecz jasna, to, co próbuje się osiągnąć w ramach SETI, jest bardzo medialne, w związku z tym ów program jest dość popularny, co jednak nie przekłada się na uznanie w kręgach naukowych. Poniekąd badacze SETI sami to przyznają:

Czytelnik może potraktować te spekulacje jako należące wyłącznie do domeny science fiction. My twierdzimy jedynie, że przedstawiona tu argumentacja pokazuje, iż istnienie sygnałów międzygwiezdnych jest całkowicie spójne z naszą wiedzą i że jeśli owe sygnały istnieją, dysponujemy obecnie narzędziami do ich odkrycia. ${ }^{6}$

Za zaletę należy jednak uznać to, że poprzez opisanie wprost najważniejszych założeń projektu, niezależnie od ich słabości, badacze SETI wykazali się cechą pożądaną przy wszelkiego rodzaju przedsięwzięciach natury naukowej intelektualną uczciwością i otwartością na krytykę.

\section{Czym jest teoria ID i jaka jest jej relacja do SETI}

Trudno jest jednoznacznie i precyzyjnie odpowiedzieć na to pytanie. W literaturze często spotyka się sformułowanie „teoria ID”, problemem jednak jest to, że — jak wspomniałem - funkcjonują różne częściowe definicje ID i trudno o w pełni zadowalające, precyzyjne określenie tego, czym ID jest. Uznajmy jednak, że zarówno SETI, jak i ID (rozumiane zarówno szeroko, jak i wąsko) to przykłady teorii. ${ }^{7}$ Pozytywistyczny pogląd, że większość teorii da się opisać

\footnotetext{
${ }^{6}$ Cocconi and Morrison, „Searching for Interstellar Communications...”, s. 846.

${ }^{7}$ Pomijając trudności z uchwyceniem tego, czym jest teoria w tym kontekście, warto nadmienić, że nawet niektórzy ze zwolenników ID nie uważają, iż można tu mówić o w pełni rozwi niętej teorii: por. Karl W. Giberson, „My Debate With an «Intelligent Design» Theorist”, The Daily Beast 21 April 2014, http://tiny.pl/grlkh (17.11.2015).
} 
w języku bardziej sformalizowanym, okazał się zbyt optymistyczny — chcąc porównać SETI i ID, musimy postarać się wydobyć odpowiednie informacje na podstawie analizy dostępnych tekstów, które reprezentują rozmaite punkty widzenia. Często teoria ID przedstawiana jest jako alternatywa dla teorii ewolucji. W takim wypadku twierdzi się, że istnieją systemy biologiczne, które nie mogły powstać na drodze neodarwinowskiej ewolucji i które zdradzają ślady zaprojektowania:

[...] inteligentny projekt jest [...] opartą na danych empirycznych teorią naukową dotyczącą początków życia - teorią, która rzuca wyzwanie materialistycznemu postrzeganiu ewolucji. ${ }^{8}$

Niektórzy uważają jednak, że teoria ID jest czymś dużo szerszym zakresowo i że biologiczne ID jest tylko jednym z jej rodzajów. Wydaje się, że ci, którzy tak uważają, idą śladem Williama Dembskiego, który opisuje ID z bardziej matematycznego punktu widzenia i uważa ją za „teorię służącą wykrywaniu i pomiarowi informacji, wyjaśnianiu jej genezy i śledzeniu jej przepływu". ${ }^{9}$ Twierdzi on również, że ,inteligentny projekt można [...] zdefiniować jako naukę, która bada ślady inteligencji”, ${ }^{10}$ co poszerza zakres zastosowania tej teorii. Wydaje się ponadto, że to Dembski spopularyzował pogląd, iż SETI, kryminalistyka $i$ tym podobne, to $\mathrm{w}$ gruncie rzeczy rodzaje ID. ${ }^{11} \mathrm{~W}$ przypadku SETI można argumentować, że istnieje jeden dokument, w którym większość założeń tej teorii została przestawiona wprost. Przypadek ID, jak widać, jest bardziej skomplikowany. Przyjmijmy na początek następującą, szeroką, definicję: teoria ID to taka teoria, której głównym elementem jest wykrywanie, czy dane zjawisko ma źródła naturalne czy sztuczne.

\footnotetext{
${ }^{8}$ Stephen C. Meyer, „Not by Chance: From Bacterial Propulsion Systems to Human DNA, Evidence of Intelligent Design Is Everywhere", National Post of Canada 1 December 2005, http://www.discovery.org/a/3059 (17.11.2015).

${ }^{9}$ William A. Dembski, ,Intelligent Design as a Theory of Information”, Access Research Network 15 November 1998, http://www.arn.org/docs/dembski/wd_idtheory.htm (17.11.2015).

${ }^{10}$ William A. DEMBSKI, „Intelligent Design”, https://billdembski.com/documents/2003.08.En cyc_of_Relig.htm (17.11.2015).

${ }^{11}$ Por. Dembski, ,Intelligent Design...”.
} 
W takim sensie jednak SETI nie może być postrzegane jako rodzaj ID, gdyż w ramach SETI nie wykrywa się istnienia sztucznego źródła badanego zjawiska, a zakłada się, że taka sytuacja ma miejsce. Nie wykrywa, ale szuka się sztucznego sygnału wysłanego z przestrzeni kosmicznej. Gdy ktoś zaproponuje mi wycieczkę do lasu w poszukiwaniu budynku, który postawili tam przybysze z obcej planety, a budynek ten wygląda zupełnie tak, jak zbudowany przez ziemian (analogia do SETI), to będzie to zupełnie inna sytuacja od tej, gdy pójdziemy do lasu, nie zakładając istnienia jakichkolwiek sztucznych obiektów, uzbrojeni tylko w kryteria odróżniania tego, co sztuczne, od tego, co pochodzi z natury. ${ }^{12}$

Założenie, że ID powinno być rozumiane w sensie węższym, mianowicie jako teorii odnoszącej się do sfery biologicznej (dla rozróżnienia nazwę tę teorię bID), również nie pozwala stwierdzić, iż SETI jest wersją ID. Dzieje się tak, rzecz jasna, w związku z tym, że bID i SETI dotyczą różnych fragmentów rzeczywistości i nie można mówić, że jedna z tych teorii jest rozszerzeniem drugiej. Przyjmijmy zatem hipotezę, że stanowią one ten sam typ teorii, dzieląc ze sobą schematy założeń, które w każdym przypadku przyjmują inną postać. Problem jednak w tym, że ciężko zorientować się, jak ów typ miałby wyglądać. Być może pomocny w tym przedsięwzięciu będzie następujący eksperyment myślowy. Rozważmy następujący zbiór założeń natury ogólnej, które mogłyby służyć jako formalizacja bID, gdyby owa teoria miała być podobna do SETI. W pozostałej części tekstu ta nowa teoria określana jest jako ID'.

[1] Istnieją systemy biologiczne, które zostały zaprojektowane.

[2] Istnieją przykłady projektów w systemach biologicznych, które są podobne do projektów, za które odpowiedzialni są ludzie [analogia do ludzi].

[3] Projekt w systemach biologicznych można wykryć po pozostawionych przez projektanta śladach [analogia do ludzi].

[4] Niektóre projekty w systemach biologicznych można wykryć, wykorzystując jako kryterium nieredukowalną lub wyspecyfikowaną złożoność [analogia do ludzi].

\footnotetext{
${ }^{12}$ Można też pokusić się o definicję ID, która obejmowałaby zarówno wykrywanie, jak i szu kanie projektu, ale podejście takie wprowadza kolejne problemy, których analiza wykracza poza ramy niniejszego artykułu.
} 
Założenie [1] nie jest obecne w bID, natomiast analogiczne założenia dotyczące istnienia sygnału nadanego przez obcą cywilizację stanowią kluczowy element teorii SETI. Co więcej, założenie [2] jest kontrowersyjne i wymaga szerszego uzasadnienia, a założenie [3], jako opierające się na założeniu [2], jest jeszcze słabsze. Założenie [4] jest szeroko dyskutowane. ${ }^{13}$ Ogólnie rzecz biorąc, można powiedzieć, że ID' jest podobna do SETI w tym sensie, że wykorzystywanie analogii do ludzkiego doświadczenia sprawia, iż ich założenia wydają się słabo uzasadnione. Jest to tym bardziej widoczne w przypadku ID', gdzie przeskok od artefaktów do projektów w systemach biologicznych (założenie [2]) jest dużo większy niż podobne przejście w przypadku SETI, gdzie analogia dotyczy tego samego tworu (sygnału), ale wytworzonego przez kogoś innego niż ludzie. ${ }^{14}$

${ }^{13}$ Por. np. H. Allen ORR, „Ponownie darwinizm kontra inteligentny projekt”, przeł. Dariusz Sagan, Filozoficzne Aspekty Genezy 2004, t. 1, s. 33-48, http://www.nauka-a-religia.uz.zgora.pl/ images/FAG/2004.t.1/art.05.pdf (17.11.2015); Jerry A. CoYNE, „Nowa fala fanatyzmu w nauce”, przeł. Dariusz Sagan, Filozoficzne Aspekty Genezy 2004, t. 1, s. 49-53, http://www.nauka-a-reli gia.uz.zgora.pl/images/FAG/2004.t.1/art.01.pdf (17.11.2015); Russell F. DoolitTle, „Subtelna równowaga", przeł. Dariusz Sagan, Filozoficzne Aspekty Genezy 2004, t. 1, s. 55-64, http://www. nauka-a-religia.uz.zgora.pl/images/FAG/2004.t.1/art.07.pdf (17.11.2015); Douglas J. FutuymA, „Cuda a molekuły”, przeł. Dariusz Sagan, Filozoficzne Aspekty Genezy 2004, t. 1, s. 65-69, http://www.nauka-a-religia.uz.zgora.pl/images/FAG/2004.t.1/art.03.pdf (17.11.2015); Mark PERAKH, „Nieredukowalna sprzeczność”, przeł. Dariusz Sagan, Filozoficzne Aspekty Genezy 2004, t. 1, s. 71-113, http://www.nauka-a-religia.uz.zgora.pl/images/FAG/2004.t.1/art.04.pdf (17.11. 2015); Michael J. BeHE, „Filozoficzne zarzuty stawiane hipotezie inteligentnego projektu: odpowiedź na krytykę", przeł. Dariusz Sagan, Filozoficzne Aspekty Genezy 2004, t. 1, s. 115-139, http://www.nauka-a-religia.uz.zgora.pl/images/FAG/2004.t.1/art.02.pdf (17.11.2015); Michael BeHE, „Nieredukowalna złożoność: problem dla ewolucjonizmu darwinowskiego”, przeł. Dariusz Sagan, Filozoficzne Aspekty Genezy 2005/2006, t. 2/3, s. 67-96, http://www.nauka-a-religia.uz. zgora.pl/images/FAG/2005-2006.t.2-3/art.01.pdf (17.11.2015); Kenneth R. MiLler, „Odpowiedź na biochemiczny argument z projektu”, przeł. Dariusz Sagan, Filozoficzne Aspekty Genezy 2005/ 2006, t. 2/3, s. 97-119, http://www.nauka-a-religia.uz.zgora.pl/images/FAG/2005-2006.t.2-3/art. 03.pdf (17.11.2015); Bruce H. Weber, „Złożoność biochemiczna. Emergencja czy projekt?”, przeł. Dariusz Sagan, Filozoficzne Aspekty Genezy 2005/2006, t. 2/3, s. 121-130, http://www.nau ka-a-religia.uz.zgora.pl/images/FAG/2005-2006.t.2-3/art.06.pdf (17.11.2015); Stephen C. MeYer, „DNA a pochodzenie życia. Informacja, specyfikacja i wyjaśnienie”, przeł. Dariusz Sagan, Filozoficzne Aspekty Genezy 2005/2006, t. 2/3, s. 133-215, http://www.nauka-a-religia.uz.zgora.pl/im ages/FAG/2005-2006.t.2-3/art.12.pdf (17.11.2015).

${ }^{14}$ Sama cywilizacja pozaziemska jest również definiowana jako pod wieloma względami podobna do tych, jakie wytworzyli ludzie. 
Fakt, że SETI zakłada, że ów sztuczny sygnał mógł zostać wytworzony i nakierowany na Ziemię, natomiast bID nie zakłada niczego podobnego odnośnie do istnienia projektu, oznacza, iż te dwie teorie nie mogą być w prosty sposób ze sobą porównane. Jednakże, jeśli bID miałaby zostać poszerzona o podobne założenie, oznaczałoby to wówczas, że teoria ta stałaby się łatwym celem dla wszystkich krytyków, co potencjalnie mogłoby oznaczać jej koniec. W takiej sytuacji zwolennicy ID mieliby bowiem problem z uzasadnieniem założenia [1] spójnym z obecną wiedzą naukową, bez odnoszenia się do podanych przez nich kryteriów wykrywania projektu, gdyż nie są one powszechnie akceptowane. Rzecz jasna, zwolennicy bID zapewne powiedzieliby, że założenie [4] jest prawdziwe, zatem założenie [1] jest niepotrzebne (bo wynika $\mathrm{z}$ tego pierwszego). Warto zauważyć, że SETI idzie jeszcze dalej i identyfikuje twórców owego sygnału jako przedstawicieli pozaziemskiej cywilizacji. Do ID’ musielibyśmy wówczas dodać założenie podobne do następującego:

[*] Byty nadprzyrodzone lub przedstawiciele obcej cywilizacji byłyby potencjalnie w stanie zaprojektować niektóre z elementów systemów biologicznych.

Jest to stwierdzenie, pod którym podpisałoby się wielu zwolenników bID uważają oni jednak, że podsumowuje ono ich przekonania natury pozanaukowej. Założenia SETI idą jeszcze dalej, stwierdzając istnienie cywilizacji pozaziemskiej, która wysłała taki sygnał. Zatem analogiczne założenie dla ID’ przyjęłoby następującą postać.

[*'] Istnieja byty nadprzyrodzone lub przedstawiciele obcej cywilizacji, które są w stanie zaprojektować niektóre $\mathrm{z}$ elementów systemów biologicznych.

Dodatkowo sprawę pogarsza fakt, że hipotezy związane z istnieniem obcych cywilizacji — nie mówiąc już o bytach nadnaturalnych — są w nauce brane pod uwagę głównie wtedy, gdy inne opcje zostały wykluczone. Hipotezy takie traktowane są jednak jako tymczasowe i ma to najczęściej charakter nieformalny, ${ }^{15}$

\footnotetext{
${ }^{15} \mathrm{Na}$ przykład, gdy odkryto sygnały pochodzące z pulsarów, ze względu na ich regularność i brak innego wyjaśnienia w danym czasie, ich źródło było żartobliwie określane jako „little green
} 
zakłada się bowiem, że „prawdziwe” — to znaczy naturalistyczne — wyjaśnienie zostanie wcześniej czy później odkryte. Sceptycyzm wobec programu SETI ma swoje źródła właśnie w takim podejściu. W ID’ sytuacja jest jeszcze ,gorsza" - pojawia się tu bowiem element nadnaturalny i nie przedstawia się innej alternatywy niż zaangażowanie ze strony cywilizacji pozaziemskiej. Na tym zakończę poszerzanie założeń ID', ale warto zauważyć, że założenia SETI idą jeszcze dalej i mniej lub bardziej szczegółowo opisują cechy owej cywilizacji pozaziemskiej. Dodatkowo twierdzi się, że poszukiwany sygnał został zaprojektowany w taki sposób, by mógł być łatwo zauważony i zaklasyfikowany jako niepochodzący z natury. Analogiczne założenia ID' musiałyby opisywać bardziej szczegółowo cechy projektanta oraz sytuację, gdzie ów projektant (potencjalnie byt nadnaturalny) pozostawił ślady w organizacji systemów biologicznych na Ziemi, w taki sposób, by zostały one przez nas wykryte i uznane za świadectwa jego istnienia. Wszystko to pokazuje, jak bardzo bID różni się od SETI i że nie można ich w łatwy sposób porównywać. W jaki sposób przekłada się to na sytuację, w której rozważa się podobieństwo bID i SETI jako tego samego typu teorii, jest kwestią bardziej złożoną. Zależy to od wielu czynników, w tym od wagi, jaką przypisuje się odpowiednim założeniom: ma to bowiem wpływ na to, w jaki sposób zbiór założeń będzie generalizowany. A to, w konsekwencji, przekłada się na różnice w definiowaniu tego typu teorii.

Adam Trybus

men”. Z kolei niedawno świat obiegła wiadomość związana z odkryciem poczynionym przez Kepler Space Telescope: znaleziono gwiazdę, której analiza wskazuje, że okrąża ją masywny obiekt, co jest niewythumaczalne zgodnie $\mathrm{z}$ obecnym stanem wiedzy. W związku z tym pojawiły się arty kuły sugerujące, że ów obiekt to megastruktura zbudowana przez obcą cywilizację (por. Ian O'Neill, „Has Kepler Discovered an Alien Megastructure?”, Discovery News 14 October 2015, http://tiny.pl/g7t91 [05.11.2015]). Sami naukowcy są jednak ostrożniejsi. Niedawno opublikowany artykuł naukowy, który dotyczy tego odkrycia, bierze pod uwagę tylko wyjaśnienia, które nie są powiązane z założeniem o istnieniu obcej cywilizacji, na przykład błąd instrumentów i tym podobne (por. T.S. BoyaJan et al., „Planet Hunters X. KIC 8462852 — Where's the Flux?”, http://ar xiv.org/pdf/1509.03622v1.pdf [05.11.2015]). 


\section{Bibliografia}

BEHE Michael J., „Filozoficzne zarzuty stawiane hipotezie inteligentnego projektu: odpowiedź na krytykę", przeł. Dariusz Sagan, Filozoficzne Aspekty Genezy 2004, t. 1, s. 115139, http://www.nauka-a-religia.uz.zgora.pl/images/FAG/2004.t.1/art.02.pdf (17.11.2015).

BeHE Michael J., „Nieredukowalna złożoność: problem dla ewolucjonizmu darwinowskiego", przeł. Dariusz Sagan, Filozoficzne Aspekty Genezy 2005/2006, t. 2/3, s. 67-96, http:// www.nauka-a-religia.uz.zgora.pl/images/FAG/2005-2006.t.2-3/art.01.pdf (17.11.2015).

Boyajian T.S. et al., „Planet Hunters X. KIC 8462852 - Where's the Flux?”, http://arxiv. org/pdf/1509.03622v1.pdf (05.11.2015).

CAMP Robert, „Czy teoria Inteligentnego projektu może być naukowa w tym samym sensie, co program SETI?", przeł. Piotr Wołkowski, Filozoficzne Aspekty Genezy 2009/2010, t. 6/7, s. 161-173, http://www.nauka-a-religia.uz.zgora.pl/images/FAG/2009-2010.t.6-7/art. 08.pdf (04.11.2015).

Cocconi Giuseppe and Morrison Philip, „Searching for Interstellar Communications”, $\mathrm{Na}$ ture 1959, vol. 184, no. 4690, s. 844-846.

Coyne Jerry A., „Nowa fala fanatyzmu w nauce”, przeł. Dariusz Sagan, Filozoficzne Aspekty Genezy 2004, t. 1, s. 49-53, http://www.nauka-areligia.uz.zgora.pl/images/FAG/2004. t.1/art.01.pdf(17.11.2015).

Dembski William A., „Intelligent Design”, https://billdembski.com/documents/2003.08.En cyc_of_Relig.htm (17.11.2015).

Dembski William A., „Intelligent Design as a Theory of Information”, Access Research Network 15 November 1998, http://www.arn.org/docs/dembski/wd_idtheory.htm (17.11.2015).

Doolittle Russell F., „Subtelna równowaga”, przeł. Dariusz Sagan, Filozoficzne Aspekty Genezy 2004, t. 1, s. 55-64, http://www.nauka-a-religia.uz.zgora.pl/images/FAG/2004.t.1/ art.07.pdf (17.11.2015).

Futuyma Douglas J., „Cuda a molekuły”, przeł. Dariusz Sagan, Filozoficzne Aspekty Genezy 2004, t. 1, s. 65-69, http://www.nauka-a-religia.uz.zgora.pl/images/FAG/2004.t.1/art.03. $\operatorname{pdf}(17.11 .2015)$.

Giberson Karl W., „My Debate With an «Intelligent Design» Theorist”, The Daily Beast 21 April 2014, http://tiny.pl/grlkh (17.11.2015).

„History of SETI”, http://archive.seti.org/seti/seti-background/ (04.11.2015). 
MeYer Stephen C., „DNA a pochodzenie życia. Informacja, specyfikacja i wyjaśnienie”, przeł. Dariusz Sagan, Filozoficzne Aspekty Genezy 2005/2006, t. 2/3, s. 133-215, http:// www.nauka-a-religia.uz.zgora.pl/images/FAG/2005-2006.t.2-3/art.12.pdf (17.11.2015).

Meyer Stephen C., „Not by Chance: From Bacterial Propulsion Systems to Human DNA, Evidence of Intelligent Design Is Everywhere", National Post of Canada 1 December 2005, http://www.discovery.org/a/3059 (17.11.2015).

MilLeR Kenneth R., „Odpowiedź na biochemiczny argument z projektu”, przeł. Dariusz Sagan, Filozoficzne Aspekty Genezy 2005/2006, t. 2/3, s. 97-119, http://www.nauka-a-religia. uz.zgora.pl/images/FAG/2005-2006.t.2-3/art.03.pdf (17.11.2015).

O’NeILL Ian, „Has Kepler Discovered an Alien Megastructure?”, Discovery News 14 October 2015, http://news.discovery.com/space/alien-life-exoplanets/has-kepler-discovered-analien-megastructure-151014.htm (05.11.2015).

ORR H. Allen, „Ponownie darwinizm kontra inteligentny projekt”, przeł. Dariusz Sagan, Filozoficzne Aspekty Genezy 2004, t. 1, s. 33-48, http://www.nauka-a-religia.uz.zgora.pl/ima ges/FAG/2004.t.1/art.05.pdf (17.11.2015).

PerakH Mark, „Nieredukowalna sprzeczność”, przeł. Dariusz Sagan, Filozoficzne Aspekty Genezy 2004, t. 1, s. 71-113, http://www.nauka-a-religia.uz.zgora.pl/images/FAG/2004.t.1/ art.04.pdf (17.11.2015).

SHоSтAK Seth, „SETI a teoria inteligentnego projektu”, przeł. Dariusz Sagan, Filozoficzne Aspekty Genezy 2009/2010, t. 6/7, s. 155-160, http://www.nauka-a-religia.uz.zgora.pl/ima ges/FAG/2009-2010.t.6-7/art.07.pdf (04.11.2015).

WeBER Bruce H., „Złożoność biochemiczna. Emergencja czy projekt?”, przeł. Dariusz Sagan, Filozoficzne Aspekty Genezy 2005/2006, t. 2/3, s. 121-130, http://www.nauka-a-religia. uz.zgora.pl/images/FAG/2005-2006.t.2-3/art.06.pdf (17.11.2015).

\section{Program badawczy SETI a teoria inteligentnego projektu}

\section{Streszczenie}

W publikacjach opisujących teorię inteligentnego projektu można napotkać argument, że program badawczy SETI jest, w jakimś sensie, powiązany z wykrywaniem projektu i w związku z tym stanowi niejako „wersję" teorii inteligentnego projektu. W niniejszym artykule, na drodze analizy podstawowego dla SETI artykułu, w którym opisano założenia tego programu badawczego, staram się wykazać, że takie zestawienie SETI i teorii inteligentnego projektu nie jest uzasadnione, gdyż jest związane $\mathrm{z}$ uproszczonym - i błędnym - rozumieniem tego, czym zajmują się naukowcy w ramach programu SETI. W tym celu porównuję SETI z teorią inteligentnego projektu w rozumieniu szerokim i wąskim, w obu przypadkach wskazując na trudności związane z próbami wykazania, iż SETI jest ,wersją" 
tak określonej teorii inteligentnego projektu. Główną przeszkodą jest to, że w ramach SETI raczej zakłada się istnienie danego artefaktu (sygnału nadanego przez cywilizację pozaziemską) niż stara się to istnienie udowodnić (wykryć projekt, jak powiedzieliby zwolennicy teorii inteligentnego projektu). W przypadku teorii inteligentnego projektu $\mathrm{W}$ rozumieniu węższym próba „dopasowania” jednej teorii do drugiej doprowadza do kuriozalnych rezultatów, co obrazuję przykładem.

Slowa kluczowe: teoria inteligentnego projektu, SETI, naukowość, filozofia biologii, wykrywanie śladów inteligencji, cywilizacje pozaziemskie.

\section{The SETI Research Programme and the Theory of Intelligent Design}

\section{Summary}

In some publications dealing with the theory of intelligent design (or perhaps one should say, $a$ theory of intelligent design, as there seem to be no universally accepted definition) one encounters an argument that the SETI research programme is, in a way, related to design detection and hence is a "version" of the theory of intelligent design. This article, by analysing the article that is foundational for SETI describing the assumptions behind this research programme, aims at showing that such a comparison of SETI and the theory of intelligent design is not justified as it is based on a simplified — and wrong — understanding of what the SETI researchers do. To this end, I compare SETI with both broad and narrow understanding of a theory of intelligent design, in both cases pointing to difficulties related to showing that SETI is a "version" of the considered theory of intelligent design. The main obstacle being that within SETI one assumes the existence of a given artefact (in this case a signal from another civilisation) rather than tries to prove that such an artefact does exist (to detect design, in the lingo of the supporters of the theory of intelligent design). In case of the narrow understanding of a theory of intelligent design, attempting to "mould" one theory so that it resembles the other shows that such an endevour is deeply flawed, as exemplified in the text.

Keywords: theory of intelligent design, SETI, science, philosophy of biology, detecting signs of intelligence, extraterrestrial civilisations. 